\title{
Türkiye Ekonomisi için 2002 Yılı Sosyal Hesaplar Matrisi
}

\author{
A Social Accounting Matrix for Turkish Economy for 2002
}

Barış GÖK${ }^{1}$, Metin KARADAĞ²

\section{ÖZET}

Bir ülkede sosyo-ekonomik aktarımları gösteren sosyal hesaplar matrisi (SHM), politika değişiklilerini analiz etmek amacıyla oluşturulan ekonomik modeller için temel veri seti olarak da kullanılmaktadır. Bu çalışmanın temel amacı, hesaplanabilir genel denge modelleri için temel veri seti teşkil edecek nitelikte Türkiye için 2002 yılına ait sosyal hesaplar matrisi oluşturmaktır. Bu amaçla en güncel veri setini oluşturmak için 2002 yılı girdi çıktı tablosu, dış ticaret istatistikleri, net vergi matrisi ve kamu kesimi istatistikleri veri kaynakları olarak kullanılmıştır. Ayrıca politika değişikliklerinin gelir dağılımı ve hane halklarının refah seviyesi üzerindeki etkilerinin analiz edilebilmesi amacıyla, hane halkı bütçe araştırması ve hane halkı tüketim harcamaları anketleri kullanılmış ve SHM'deki hane halkı hesabı gelir seviyesi (\% 20'lik dilimler halinde) ve yerleşim yerine göre (kent, kır) 10 farklı gruba ayrıştırımıştır. Bu çalıșmada SHM'nin temel özelliklerine kısaca değinildikten sonra, Türkiye ekonomisi için 2002 yılına ait SHM'nin oluşturulma yöntemi ayrıntılı olarak açıklanmıştır.

Anahtar Kelimeler: Türkiye, sosyal hesaplar matrisi (SHM), gelir dağılımı.

\section{GíRiş}

Sosyal hesaplar matrisi (SHM), bir ülkede sosyo-ekonomik sistemdeki aktarımların matris olarak gösterimi, ekonomik çevrimin kaynak dağılımını da belirten nümerik ifadesi olarak tanımlanmaktadır (Round, 2003a:162; Keuning \& Ruijter, 1988:72) ${ }^{1}$. SHM, ekonomide yaratılan gelirin hangi üretim aktivitelerince oluşturulduğunu ve bunun sosyal ve kurumsal gruplar arasında nasıl bölüşüldüğünü ayrıntılı olarak göstermektedir. Dolayısıyla SHM her hesabın harcamasının başka bir hesabın geliri olarak kaydedildiği çift girişli muhasebe sistemine dayanan ve satır sütun toplamları birbirine eşit olan kare bir matristir. Bu yönleriyle SHM, ekonomi çapındaki ilişkileri sergileyen, ekonomik birimler arasındaki yapısal ilişkileri tablolaştıran bir veri tabanı ve hesap sistemi olarak ifade edilebilir (Telli, 2004: 9).

\begin{abstract}
A social accounting matrix (SAM), which represents the transactions of a socio-economic system in a country, can also be utilized as a fundamental data set for economic models to address policy questions. The aim of this study is to construct a SAM for the year of 2002, which can be used as the data set for the computable general equilibrium model constructed to analyze the tax policy changes in Turkey. For this purpose, 2002 input-output table, foreign trade statistics, net tax matrix and public sector statistics were used as data sources. Also, in order to analyze the effects of policy changes on income distribution and welfare, household account was disaggregated into 10 representative groups according to their income size (by quintiles) and settlement (urban, rural) by employing household budget surveys and household consumption expenditures surveys. In this paper, after giving the main features of the SAM very briefly, the procedure of construction of the SAM for Turkish economy for the year of 2002 was explained in detail.
\end{abstract}

Keywords: Turkey, social accounting matrix (SAM), income distribution.

Sosyal hesaplar matrisi ekonomi ile ilgili oldukça detaylı veri setini içermektedir. Bu bağlamda, SHM ekonomi politikası değişikliklerinin gelir dağılımı, refah seviyesi, kaynak dağılımı gibi ekonomik etkilerinin analiz edilmesi amacıyla inşa edilen hesaplanabilir genel denge (HGD) modellerinde temel veri seti olarak kullanılmaktadır (örneğin bkz. Konan ve Maskus, 2000; Mabugu, 2001; Decaluwé, vd., 2005; Chemingui ve Dessus, 2008)².

Literatürde birçok ülke için oluşturulmuş SHM bulunmaktadır. Bunlardan Amerika Birleşik Devletleri (Reinert ve Roland-Holst, 1992), Hindistan (Pradhan, vd., 1999; Deb Pal, vd., 2012), Tunus (Salem, 2004), Gana (Breisinger, vd., 2007), Mısır (Thissen ve Lofgren, 1998), Mozambik (Robinson, vd., 2001), Pakistan (lqbal ve Siddiqui, 1998; Debowicz, vd., 2012), Tayland (Li, 2002), Nijerya (Nwafor, vd., 2010), Libya (Dewhurst, vd., 2011) ve Türkiye (Köse ve Yeldan,

\footnotetext{
${ }^{1}$ Araş. Gör. Dr., Ege Üniversitesi, İktisadi ve İdari Bilimler Fakültesi, İktisat Bölümü, baris.gok@ege.edu.tr 
1996; de Santis ve Ozhan, 1997; Karadag ve Westaway, 1999; Telli, 2004; Erten, 2009; Gedik, 2011; Akkemik, 2012), için oluşturulmuş olan SHM'ler örnek olarak verilebilir.

Türkiye ekonomisi için inşa edilen SHM çalışmalarından De Santis ve Özhan (1997), 1990 yılı girdi çıktı tablosunu temel alarak, HGD modellerinde kullanılmak üzere 54 sektörlü SHM oluşturmuşlardır. İlgili SHM'deki işgücü hesabı, sermaye hesabı, hane halkı hesabı ve firmalar hesabı çeşitli düzeylerde ayrıştırılmıştır. Karadağ ve Westaway (1999)'un, 1990 yılı girdi çıktı tablosunu temel alarak aynı yıl için oluşturdukları 11 sektörlü SHM, hane halkı gelir ve harcama anketlerinden yararlanılarak yerleşim yeri ve gelir düzeyine göre ayrıştırılmış 6 farklı hane halkı grubunu içermektedir.

Literatürde Türkiye ekonomisi için 2002 ve sonrası yıllara ait olarak oluşturulan SHM çalışmaları vardır (örneğin. Telli 2004, Erten 2009, Gedik 2011, Akkemik 2012). Bunlardan Telli (2004), Türkiye ekonomisinin toplulştırılmış düzeyde SHM zaman serilerini veren bir üretim hattı sisteminin geliştirilmesiyle 1996 2003 yılları arası için 8 farklı SHM oluşturmuştur. Oluşturulan SHM'ler tek sektörlü, işgücü hesabında kayıtlı ve kayıt dışı ayrımını ve ayrı bir hesap olarak SGK ve yerleşik bankaları içermektedir. Benzer bir çalışma olan Erten (2009), çalışmasında geliştirdiği SHM üretme yöntemini kullanarak 1998 yılından 2006 yılına kadar her bir yıl için 9 farklı SHM oluşturmuştur. Telli (2004)'ten farklı olarak, çalışmada oluşturulan SHM'ler 9 sektörlü olup, sermaye hesabında kamu ve özel sermaye hesabı ayrımını içermektedir. Gedik (2011), 1998 ve 2002 yılları girdi çıktı tablolarını temel alarak ilgili yıllar için 21 sektörlü SHM oluşturmuştur. Çalışmada oluşturulan SHM'lerde sosyal güvenlik sistemi ayrı bir hesap olarak yer almaktadır. İlgili SHM'ler bu yönüyle önceki çalışmalarda oluşturulan SHM'lere benzerlik gösterse de sektör sayısı ve girdi çıktı tablolarına dayan yapısı yönünden öncekilerden farklı olduğu belirtilebilir. Benzer şekilde Akkemik (2012), 1996 ve 2002 yılları girdi çıktı tablolarına dayanarak ilgili yıllar için 21 sektörlü SHM oluşturmuştur. Bu çalışmada turizm sektörünün analizi için oluşturulan SHM'ler, ilgili yıllara ait girdi çıktı tablolarının genişletilmiş hali olarak düşünülebilir. Girdi çıktı tablolarından ve önceki SHM oluşturma çalışmalarından farklı olarak, yerli turizm ve uluslararası turizm olmak üzere iki farklı sektör, turizm anketlerinden yararlanılarak SHM'lere eklenmiştir.

$\mathrm{Bu}$ çalışmanın temel amacı, son yıllarda yapılan vergi politikası değişikliklerini analiz etmek amacıyla
Türkiye ekonomisi için oluşturulan bir HGD modelinin temel veri setini teşkil edecek nitelikte SHM inşa etmektir. Bu bağlamda Türkiye ekonomisi için yayımlanan en güncel girdi çıktı tablosu 2002 yılı girdi çıktı tablosu olduğundan, bu tablo temel alınarak 2002 yılına ait 15 sektörlü bir SHM inşa edilmiştir. ${ }^{3}$ Türkiye ekonomisi için daha önce oluşturulan 2002 yılına ait SHM'lerinden farklı olarak, 2002 yılı bütçe ve tüketim harcamaları anketleri kullanılarak hane halkı hesabı yerleşim yeri (kent, kır) ve gelir seviyesine göre (\% 20'lik dilimler halinde) 10 farklı gruba ayrıştırılmıştır. Hane halkı hesabının 10 farklı gruba ayrıştırılması, politika değişikliği analizlerinde ilgili değişikliğin gelir dağılımı ve farklı hane halkı gruplarının refah seviyeleri üzerindeki etkilerinin de analiz edilmesine olanak sağlamaktadır.

SHM'nin oluşturulabilmesi için verilerin değişik kaynaklardan toplanması gerekmektedir. Bunlar girdi-çıktı tabloları, kamu kesimi bütçe istatistikleri, dış ticaret istatistikleri, vergi istatistikleri, hane halkı bütçe anketleri şeklinde sıralanabilir. SHM oluşturmanın zorluğu farklı kurumlardan elde edilen bu istatistiklerin genellikle tutarsız olmasından kaynaklanmaktadır. Bir kurumdan elde edilen istatistik, farklı muhasebe ve hesap işlemleri ile oluşturulduğundan, diğer kurumdan elde edilen istatistik ile farklı olabilmekte ve edinilen rakamlar birbirini tutmamaktadır. Bu nedenle ilgili istatistiklerin ayrıntılı bir şekilde incelenmesi ve karşılaşılacak tutarsızlıkların aşılması için çeşitli yöntemlerin kullanılması gerekmektedir. Bu yöntemler incelenen istatistiklerin alt kalemlerine inerek tutarsızlıkların kaynaklarının bulunarak giderilmesi olabileceği gibi, SHM satır ve sütun toplamlarının birbirine eşit olması gerekliliği ilkesinden yararlanılarak bilinmeyen hücre değerinin tahmininde kullanılan RAS (Row And column Sum) yöntemi ya da çapraz entropi (cross entropy) gibi daha karmaşık optimizasyona dayalı yöntemler de olabilir.

Çalışmanın 2. kısmında SHM'lerin temel yapısı tanımlanacak, 3. kısımda ise 2002 yılı için oluşturulan Türkiye SHM'si açıklanacaktır. Son kısım çalışmanın sonuç bölümüdür.

\section{SOSYAL HESAPLAR MATRISI VE TEMEL YAPISI}

Kare matris biçiminde muhasebe kaydının kökenleri oldukça eskilere dayansa da SHM'nin ilk kapsamlı örneği olarak genellikle Stone, Brown ve meslektaşlarının 1960'lı yıllarda İngiltere ve bazı endüstrileşmiş ekonomiler için yürüttükleri Cambridge Büyüme Projesi kapsamında oluşturdukları SHM gösterilmektedir (Round, 2003b:2; Pyatt \& Round, 1977:341)4. 
Stone'un yaptığı çalışmalardan en bilineni, 1960'lı yıllarda geliştirdiği ve SHM'nin oluşturulmasında temel teşkil eden Ulusal Hesaplar Sistemi'nin ${ }^{5}$ (System of National Accounts, SNA) ${ }^{6}$ geliştirilmesi olarak belirtilmektedir (Pyatt, 1994b:123).

SHM bir ekonomide sektörler itibariyle katma değerin üretim faktörlerince nasıl yaratıldığını ve bu üretim faktörlerinin kurumsal sahipliğini, elde edilen gelirin nasıl harcandığını, mallara yapılan tüketim harcamasının ne kadarlık bir sektörel üretime ve katma değere neden olduğunu göstermektedir. Ekonomik çevrimin içerisindeki bu bağlantılara aynı şekilde yurtdışına yapılan ödemeler veya elde edilen tasarruflar da eklenmektedir (Keuning \& Ruijter, 1988: 72). Ayrıca SHM, ekonomideki her bir gelirin karşılığı ilgili bir gider ya da harcama olduğunu etkin ve kolay bir şekilde göstermektedir. Bu yönleriyle ekonominin bütününü kurumsal ve sektörel ayrımları ve bunlar arasındaki ilişkilerle birlikte ayrıntılı olarak nümerik olarak sergileyen SHM, HGD modelleri için de temel veri kaynağı oluşturmaktadır (örneğin bkz. Ulussever, 2011; Gedik, 2010; Saraçoğlu, 2008; Karadag \& Westaway, 1999).

SHM'nin temelde iki amacı bulunmaktadır. Bunlardan ilki genellikle bir ülke, bölge ya da şehir için belli bir yıla ait ekonomik ve sosyal yapıyı ortaya koyan bilgiyi organize etmektir. Belirli bir yıla ait bölge ya da ülkenin verileri SHM biçiminde tablolaştırıldığında bu tablo ekonomik yapı hakkında oldukça ayrıntılı bilgiler vermektedir. Söz konusu SHM'nin, ekonominin ilgili yıldaki temel görüntüsünü verdiği söylenebilir. Fakat politika değişikliklerinin ilgili ekonomiye etkisini ölçmek ve değerlendirmek için statik bir görüntüden daha fazlasına ihtiyaç duyulmaktadır.
$\mathrm{Bu}$ tür analizler tutarlı modeller gerektirmektedir. Dolayısıyla SHM'nin ikinci amacı, bu tür ekonomik modeller için oldukça ayrıntılı bir veri seti oluşturmaktır (King, 1981:1).

SHM'ler ekonomideki hane halkları ve devlet gibi ekonomik birimlerin, işgücünün, beşeri sermayenin ve sosyal refahın durumu hakkında ayrıntılı bilgi verecek şekilde genişletilip geliştirilebilirler. Bu anlamda ilgili ülke ya da bölgenin sosyo-ekonomik durumu hakkında ayrıntılı bilgi sağlamaktadırlar. Bunun ötesinde SHM, ulusal istatistikler arasındaki tutarsızlıkların ve boşlukların da kontrol edilmesini sağlamaktadır.

En temel haliyle standart bir SHM, üretim, faktörler, ekonomik birimler, birikim ve dış alem olmak üzere beş temel hesap altında gösterilebilir. Faktörler olarak belirtilen kısımda en temel şekliyle emek ve sermaye gibi üretim faktörleri, ekonomik birimler olarak ifade edilen kısımda ise hane halkı ve devlet (kamu kesimi) bulunmaktadır.

Ekonomik faaliyetin temeli olan üretim, SHM'nin en önemli birimi olarak ifade edilebilir. SHM'de bulunan üretim hesabı üretim faaliyetleri ve ürünler hesaplarından oluşmaktadır. Üretim faaliyetleri hesabının ürünler hesabından ayrılması, bir üretim faaliyetinin birkaç çeşit ürün üretimini sağlamasının ve aynı zamanda bir ürünün birkaç çeşit faaliyet sonucu üretilmesinin gözlemlenmesine olanak sağlamaktadır. Üretici fiyatlarıyla elde edilen gelirler üretim faaliyetleri hesabına, piyasa fiyatlarıyla elde edilen gelirler (dolaylı vergiler ve ulaşım maliyetleri dahil) ürünler hesabına kaydedilmektedir. Ürünler ithalatın ve üretim faaliyetlerinin bir sonucu olarak ihraç edilmekte ya da yurtiçinde satılmaktadır. Ürünler

Tablo 1: Makro SHM

\begin{tabular}{|c|c|c|c|c|c|c|c|}
\hline & $\begin{array}{c}\text { Üretim } \\
\text { Faaliyetleri }\end{array}$ & Ürünler & Faktörler & $\begin{array}{c}\text { Hane } \\
\text { Halkı }\end{array}$ & Devlet & Birikim & $\begin{array}{c}\text { Dış } \\
\text { Alem }\end{array}$ \\
\hline Üretim Faaliyetleri & & $\mathrm{X}^{\mathrm{XD}}$ & & & & & $\mathrm{E}$ \\
\hline Ürünler & & & & $\mathrm{CD}$ & $\mathrm{G}$ & $\mathrm{I}$ & \\
\hline Faktörler & $\mathrm{X}$ & & & & & & \\
\hline Hane halkı & & & $\mathrm{Y}$ & & & & \\
\hline Devlet & $\mathrm{T}^{\mathrm{X}}$ & & & $\mathrm{T}^{\mathrm{H}}$ & & & \\
\hline Birikim & & & & $\mathrm{S}^{\mathrm{H}}$ & $\mathrm{S}^{\mathrm{G}}$ & & $\mathrm{S}^{\mathrm{F}}$ \\
\hline Dış Alem & & $\mathrm{M}$ & & & & & \\
\hline
\end{tabular}

(Kaynak: Robinson, 2006:207) 
sütununda ödemeler yerli faaliyetlere, dış dünyaya ve vergi hesabına yapılmaktadır. SHM'de endüstriler, üretim faaliyetleri sonucu yaptıkları üretimin bir kısmını ürünler hesabına satmakta, geri kalanını da ihraç etmektedir. Daha sonra ürünler hesabı, çıktısının bir kısmını ara girdi olarak kullanılmak üzere üretim faaliyetlerine, kalanını da hane halkı ve devlet gibi nihai kullanıcılara nihai talep olarak satmaktadır.

Tablo 1'de basit bir makro SHM gösterilmiştir. Tabloda hesapların satırları boyunca gidildiğinde sırasıyla $X^{\times D}$ yurtiçi satışları; $E$ ihracatı; $C D, G$ ve I hane halkı, kamu kesimi ve yatııım nihai taleplerini; $T^{\mathrm{X}}$ ve $\mathrm{T}^{\mathrm{H}}$ dolaylı ve doğrudan vergileri; $\mathrm{S}^{\mathrm{H}}, \mathrm{S}^{\mathrm{G}}$ ve $\mathrm{S}^{\mathrm{F}}$ hane hal$\mathrm{kı}$, kamu kesimi ve yabancı tasarrufları; $M$ ise ithalatı göstermektedir. Tabloda $X$ ve $Y$ ise sırasıyla toplam üretimi ve hane halkına yapılan faktör ödemelerini belirtmektedir.

Tablo 1'de, üretim faaliyetleri satırı, sütunda bulunlar ürünler hesabından $\mathrm{X}^{\mathrm{XD}}$ kadar, dış alem hesabından ise E kadar gelir elde etmektedir. Üretim faaliyetleri sütunu ise üretimini gerçekleştirebilmek için faktörler hesabına üretim faktörlerinin payını ödemekte, ayrıca devlete bu faaliyetler sonucu dolaylı vergiler ödemektedir. Bu durumda birinci satır ve birinci sütunun matematiksel özdeşliği aşağıdaki gibi ifade edilmektedir.

$$
\text { GSYIH }=X+T^{X}=X^{X D}+E
$$

Yukarıdaki denklemde $X$ üretim faktörlerine yapılan amortisman dahil ödemeleri, $\mathrm{T}^{\mathrm{X}}$ dolaylı vergileri içerdiğinden bu ifade gelir yaklaşımılla GSYiH'yı ifade etmektedir. Bu durumda $X$ faktör maliyetleri ile GSYiH'yı göstermekte ve Y'ye eşit olmaktadır.

Ürünler hesabı sütunu, üretim faaliyetlerinden ve ithalattan aldığı çıktıyı nihai tüketime vermektedir. Bu durumda ürünler hesabının satır ve sütun denkliğinin matematiksel ifadesi aşağıdaki gibi ifade edilmektedir.

$$
X^{X D}+M=C D+G+I
$$

Denklem 1 yardımıyla yukarıdaki ifadeden harcamalar yaklaşımıyla GSYiH aşağıdaki gibi bulunabilir.

$$
G S Y I H+(M-E)=C D+G+I
$$

Aşağıda, denklemlerle belirtilen diğer hesapların satır ve sütun eşitlikleri de sırasıyla hane halkı gelir ve giderleri, kamu dengesi, yatırım tasarruf denkliği ve dış alem denkliği için ifade edilmektedir.

$$
\begin{aligned}
& Y=C D+T^{H}+S^{H} \\
& T^{X}+T^{H}=G+S^{G} \\
& I=S^{H}+S^{G}+S^{F}
\end{aligned}
$$

$$
M=E+S^{F}
$$

Yukarıda açıklanan makro SHM'nin cebirsel işlemler sonucunda gösterdiği temel özellik, matrisin satır ve sütun toplamlarının birbirine eşit olması gerekliliği durumudur. Bu durum ekonomideki yatırım tasarruf, dış alem ve kamu kesimi dengesi gibi makro dengelerin SHM bünyesinde dengede olması gerekliliğine işaret etmekte, Walrasgil dengenin HGD modellerinde olduğu gibi onun veri setini oluşturan SHM için de geçerli oluğunu göstermektedir.

Sosyal hesaplar matrisi oluşturmanın başlangıç noktası genişletilmiş girdi-çıktı tabloları olarak düşünülebilir. SHM, girdi-çıktı tablolarından farklı olarak devletin, hane halklarının ve ekonomideki diğer birimlerin gelir ve gider anlamındaki bilgilerini içermektedir. Dolayısıyla SHM, genişletilmiş girdi-çıktı tablosundan temelde, ekonomideki birimler arası her türlü gelir akımlarını ayrıntılı olarak göstermesi yönüyle farklılık göstermektedir (Pyatt, 1999: 366). $\mathrm{Bu}$ nedenle girdi-çıktı tablolarına dayanıyor olsa da SHM oluşturmak için daha başka birçok veriye ihtiyaç duyulmaktadır. SHM, ekonominin ne kadar ayrıntılı olarak incelenmek istendiğine ve hazırlanacak olan SHM için gereksinim duyulan verilerin erişilebilirliğine bağlı olarak istenildiği ölçüde genişletilebilir. İzleyen kısımda Türkiye ekonomisi için oluşturulmuş SHM'nin yapısına değinilecektir.

\section{TÜRKIYE IÇIN SHM OLUŞTURULMASI}

Bu çalışmada Türkiye ekonomisi için 2002 yılına ait SHM oluşturulmuştur. SHM'nin toplulaştırılmış şematik yapısının ifade edildiği Tablo 2'den de görüldüğü gibi SHM, Tablo 1'de gösterilen temel yapıya uygun olarak üretim faaliyetleri, ürünler, faktörler, ekonomik birimler, birikim ve dış alem bloklarından oluşmaktadır. Üretim faaliyetleri ve ürünler blokları, Tablo 3'te gösterilmiş olan 15 alt sektöre ayrıştırılmıştır. Faktörler bloğu emek ve sermayeden, ekonomik birimler bloğu ise hane halkı bloğu ve devlet hesabından meydana gelmiştir. Hane halkı bloğu ilk olarak kent ve kır yerleşik olmak üzere iki gruba, her grup da \% 20'lik gelir gruplarına göre kendi içinde 5 gruba bölünerek toplamda 10 gruba ayrıştırılmıştır. Böylece SHM, 46×46 boyutunda bir kare matris olarak elde edilmiştir.

SHM hücrelerindeki değerler 2002 yılı cari fiyatlar cinsinden miktar $\times$ fiyat olarak ifade edilmiştir. SHM oluşturulurken TÜiK tarafından açıklanan en güncel girdi-çıktı tablosu olan 2002 yılı girdi-çıktı tablosu ve net vergi matrisi kullanılmıştır. Bunun yanında, SHM'ye kamu kesimini tutarlı biçimde girebilmek amacıyla T.C. Başbakanlık Hazine Müsteşarlığı ve DPT 
Tablo 2: Toplulaştırılmış SHM Şematik Görünümü

\begin{tabular}{|c|c|c|c|c|c|c|c|c|c|}
\hline & $\begin{array}{c}\text { Üretim } \\
\text { Faaliyetleri }\end{array}$ & Ürünler & İ̧̇gücü & Sermaye & Hane Halkı & Devlet & Birikim & Dış Alem & Toplam \\
\hline $\begin{array}{l}\text { Üretim } \\
\text { Faaliyetleri }\end{array}$ & & $\begin{array}{l}\text { Yurtiçi } \\
\text { Satışlar }\end{array}$ & & & & & & İhracat & Toplam Satışlar \\
\hline Ürünler & Ara Girdiler & & & & Özel Tüketim & $\begin{array}{c}\text { Kamu } \\
\text { Tüketimi }\end{array}$ & Yatırımlar & & $\begin{array}{c}\text { Yurtiçi Toplam } \\
\text { Talep }\end{array}$ \\
\hline İşgücü & Ücretler & & & & & & & & İşgücü Geliri \\
\hline Sermaye & $\begin{array}{l}\text { Sermaye } \\
\text { Geliri }\end{array}$ & & & & & & & & Sermaye Geliri \\
\hline Hane Halkı & & & Ücretler & $\begin{array}{l}\text { Sermaye } \\
\text { Geliri }\end{array}$ & & Transferler & & $\begin{array}{c}\text { Net } \\
\text { Faktör } \\
\text { Gelirleri }\end{array}$ & $\begin{array}{l}\text { Hane Halkı } \\
\text { Gelirleri }\end{array}$ \\
\hline Devlet & $\begin{array}{l}\text { Dolaylı } \\
\text { Vergiler }\end{array}$ & $\begin{array}{c}\text { İthalat } \\
\text { Vergileri }\end{array}$ & & & $\begin{array}{l}\text { Doğrudan } \\
\text { Vergiler }\end{array}$ & & & & Kamu Gelirleri \\
\hline Birikim & & & & & Özel Tasarruf & $\begin{array}{c}\text { Kamu } \\
\text { Tasarrufu }\end{array}$ & & $\begin{array}{c}\text { Dış } \\
\text { Kaynak }\end{array}$ & $\begin{array}{c}\text { Toplam } \\
\text { Tasarruflar }\end{array}$ \\
\hline Dış Alem & & İthalat & & & & & & & $\begin{array}{c}\text { Döviz } \\
\text { Harcamaları }\end{array}$ \\
\hline Toplam & $\begin{array}{c}\text { Toplam } \\
\text { Maliyetler }\end{array}$ & Toplam Arz & $\begin{array}{l}\text { İşgücü } \\
\text { Maliyeti }\end{array}$ & $\begin{array}{l}\text { Sermaye } \\
\text { Maliyeti }\end{array}$ & $\begin{array}{l}\text { Hane Halkı } \\
\text { Harcamaları }\end{array}$ & $\begin{array}{c}\text { Kamu } \\
\text { Harcamaları }\end{array}$ & $\begin{array}{l}\text { Toplam } \\
\text { Yatırımlar }\end{array}$ & $\begin{array}{c}\text { Döviz } \\
\text { Gelirleri }\end{array}$ & \\
\hline
\end{tabular}

(Kaynak: Karadağ \& Westaway, 1999:20; Telli, 2004:18; Erten, 2009:99'dan yararlanılarak geliştirilmiştir.)

tarafından yayınlanan Kamu Kesimi Genel Dengesi (KKGD) ve bütçe istatistiklerinden, dış dengenin tutarlılığının sağlanması amacıyla TCMB tarafından yayınlanan ödemeler dengesi istatistiklerinden, TÜiK'ten edinilen ithalat vergisinin sektörel dağılım istatistiklerinden ve milli gelir hesaplarından faydalanılmıştır. Ayrıca hane halkının 10 farklı alt gruba ayrıştırabilmesi için yine TUIK tarafından yayınlanan 2002 yılı hane halkı bütçe araştırması anketleri ve 2002 yılı hane halkı tüketim harcamaları anketleri kullanılmıştır.

Daha önce de belirtildiği gibi SHM'lerin temel veri kaynağını girdi-çıktı tabloları oluşturur. Bu sebeple SHM hazırlanırken öncelikle kullanılacak olan girdi-çıktı tablosunun yapısı ile oluşturulmak istenen SHM yapısının birbirine uyumlaştırılması gerekmektedir. Bu amaçla 59 ürün grubundan oluşan 2002 yılı girdi-çıktı matrisi, 15 ürün grubuna toplulaştırılmıştır. Bu toplulaştırma aynı şekilde net vergi matrisinde de yapılmıştır. Tablo 3'te girdi-çıktı matrisi ve net vergi matrisindeki hangi sektörlerin bu çalışmada oluşturulan SHM'de hangi sektör adı altında toplulaştırıldığı görülmektedir.

Bütün akımların tanımlarının açık bir şekilde belirtilebilmesini sağlamak amacıyla üretim faaliyetleri bloğu, ürünler bloğu ve hane halkı bloğu Tablo 2'de
Tablo 3: Türkiye Girdi-Çıktı Tablosundaki Toplulaştırılan Sektörler

\begin{tabular}{|c|c|}
\hline $\begin{array}{l}2002 \text { Yılı Girdi-Çıktı } \\
\text { Tablosundaki Sektör } \\
\text { Kodu }\end{array}$ & $\begin{array}{l}\text { Oluşturulan SHM'deki } \\
\text { Sektör Adı }\end{array}$ \\
\hline $1-3$ & 1. Tarım \\
\hline $4-8$ & 2. Madencilik \\
\hline $9-10$ & 3. Gıda İçecek ve Tütün Ürünleri İmalatı \\
\hline 11-13 & 4. Tekstil Ürünleri \\
\hline $14-16,30$ & 5. Ağaç Sanayi \\
\hline $17-20$ & 6. Yakıt ve Metal olmayan Ürünler Sanayi \\
\hline $21-22$ & 7. Metal Sanayi \\
\hline $23-29,31$ & 8. Makine ve Teçhizat İmalatı \\
\hline $32-33$ & 9. Elektrik, Gaz, Su \\
\hline 34 & 10. Inşaat \\
\hline 38 & 11. Oteller ve Lokantalar \\
\hline $39-43$ & 12. Ulaştırma ve Haberleşme Hizmetleri \\
\hline 52,55 & 13. Kamu Hizmetleri \\
\hline $50,53-54$ & 14. AR-GE, Eğitim ve Sağlık işleri \\
\hline $35-37,44-49,51,56-59$ & 15. Diğer Hizmetler \\
\hline
\end{tabular}

toplulaştırılmış olarak gösterilmiştir. Tablo 4'te, tanımlamaları Tablo 2'de verilmiş olan, Türkiye ekonomisinin 2002 yılına ait makro SHM görülmektedir? İlgili SHM'deki tüm rakamlar 2002 yılı fiyatlarıyla bin YTL cinsindendir. İlgili tabloda gösterilen SHM'de dolu olan hücrelerinin nasıl oluşturulduğu devam eden kısımda sütunlar boyunca sırasıyla açıklanmaktadır. 
Tablo 4: Türkiye için 2002 Yılı Makro SHM (Bin TL)

\begin{tabular}{|c|c|c|c|c|c|c|c|c|c|}
\hline & Faaliyetler & $\begin{array}{c}\text { Mal ve } \\
\text { Hizmetler }\end{array}$ & İşgücü & Sermaye & Hanehalkı & Devlet & Birikim & Dış Alem & Toplam \\
\hline Faaliyetler & & 610534 & & & & & & 64494 & 675029 \\
\hline Mal ve Hizm. & 329919 & & & & 259460 & 44615 & 61731 & & 695725 \\
\hline İşgücü & 92431 & & & & & & & & 92431 \\
\hline Sermaye & 210889 & & & & & & & & 210889 \\
\hline Hanehalkı & & & 92431 & 210889 & & 34988 & & 6143 & 344451 \\
\hline Devlet & 41790 & 700 & & & 41633 & & & & 84123 \\
\hline Birikim & & & & & 43358 & 4521 & & 13853 & 61731 \\
\hline Dış Alem & & 84490 & & & & & & & 84490 \\
\hline Toplam & 675029 & 695725 & 92431 & 210889 & 344451 & 84123 & 61731 & 84490 & \\
\hline
\end{tabular}

( Kaynak: Yazarların kendi hesaplamaları.)

\section{1. Üretim Faaliyetleri Hesabı}

Bu çalışmada oluşturulan SHM'deki üretim faaliyetleri sütun ve satırı, Tablo 3'te belirtilen 15 sektörlerden oluşmaktadır. Dolayısıyla Tablo 2 ve Tablo 4'teki üretim faaliyetleri sütunu ile üretim faaliyetleri satıının kesiştiği hücre, bu çalışmada hazırlanan SHM'de $15 \times 15$ boyutunda bir matrisi ifade etmektedir. Üretim faaliyetleri sütunu, yurtiçinde üretim yapan sektörlerin üretim sürecinde katlandıkları maliyetleri göstermekte, satırı ise ilgili üretimin hangi piyasalara arz edildiğini göstermektedir.

SHM'de hangi hücrelerde hangi değerlerin bulunması gerektiği Tablo 2'de gösterilmektedir. SHM'de üretim faaliyetleri sütunu boyunca ilerlendiğinde (bu çalışmada oluşturulan SHM'de sütunda 1-15 numaraIı hesaplar), üretim faaliyetleri sütunu ve ürünler satırının kesiştiği yerde bulunan "ara girdiler" (bkz. Tablo 2) hücresi, SHM'de 15 üretim sektörü ve 15 ürünün bulunduğu $15 \times 15$ boyutunda bir ara mal kullanım matrisini ifade etmektedir. Tablo 2'de "ara girdiler" olarak ifade edilen bu matris, bu çalışmada oluşturulan SHM'nin satırında 16-30, sütununda 1-15 numaralı hesaplar arasında görülmekte ve sütunda yer alan sektörün üretimini yapabilmesi için satırda yer alan üründen kullanılması gereken ara mal miktarlarını göstermektedir. SHM'nin bu kısmı, toplulaştırılmış girdi-çıktı tablosundaki ürünler satırı ve sütununun kesiştiği yerde bulunan ara kullanımlar matrisinden elde edilmiştir.

Üretim faaliyetleri sütunu ile işgücü satırının kesiştiği yerde bulunan "ücretler" matrisi yatay bir vektör olup SHM'de satırda 31, sütunda 1-15 numaralı hesaplar arasında bulunmaktadır. Bu kısım her bir üretim sektörünün üretimini gerçekleştirmek için işgücüne yapması gereken ödeme miktarını göstermektedir ve toplulaştırıımış girdi-çıktı tablosundaki "çalışanlara yapılan ödemeler" satıından alınmıştır. Aynı sütun ile sermaye satıının kesiştiği yerde bulunan "sermaye geliri", SHM'de satırda 32, sütunda
1-15 numaralı hesaplar arasında bulunmakta ve her bir üretim sektörünün üretimini gerçekleştirebilmek için sermayeye yaptığı ödemeyi göstermektedir. SHM'deki bu kısım, toplulaştırılmış girdi-çıktı tablosundaki amortismanları da içeren "işletme artığı, gayrisafi" satırından alınmıştır.

SHM'de Üretim faaliyetleri sütunu ile devlet satırının kesiştiği yerde görülen "dolaylı vergiler", (SHM'de 43 numaralı satır ve 1-15 numaralı sütun) ilgili sektörce ödenen dolaylı vergileri içermektedir. Bu nedenle bu kısım, toplulaştııılmış girdi-çıktı tablosundaki "ürün üzerindeki net vergiler" satırının girilmesiyle oluşturulmuştur. Ancak SHM'deki "dolaylı vergiler" hücresi satış vergilerini içermekte fakat ithalat vergilerini içermemektedir. Bu nedenle TÜiK tarafından yayınlanan 2002 yilı net vergi matrisindeki "nihai kullanımlar" vergileri de, TÜiK'ten edinilen 2002 yılı sektörel ithalat vergileri çıkartılarak bu kısma eklenmiştir. Dolaylı vergiler hesabının da açıklanmasıyla bu çalışmada oluşturulan SHM'de üretim faaliyetleri sütunu boyunca dolu olan hücrelerde yer alan değerlerin nasıl elde edildiği açıklanmıştır.

\section{2. Ürünler Hesabı}

Bu çalışmada hazırlanan SHM'de ürünler hesabı Tablo 3'teki 15 sektörden oluşmaktadır. Ürünler sütunu ile üretim faaliyetleri satıının kesiştiği yerde bulunan "yurtiçi satışlar", yalnızca köşegeninde rakamlar bulunan, satır ve sütunları aynı sektörlerden oluşan $15 \times 15$ boyutundaki bir kare matristen oluşmaktadır (SHM'de satırda 1-15 sütunda 16-30 numaralı hesaplar).

Ürünler sütunu yurtiçi piyasaya yapılan mal ve hizmet arzının kaynağını ayrışırmakta, satırı ise ilgili mal ve hizmetlerin talep kaynaklarını göstermektedir. Buna göre ekonomideki toplam arz yurtiçi satışlar ve ithalattan oluşmakta, bu arz da üretim faaliyeti sırasında ara mal olarak kullanılmakta, özel tüketim, kamu tüketimi ve yatırım harcaması olarak talep edilmektedir. 
SHM'de üretim faaliyetleri ve ürünler hesabının ayrı ayrı gösterilmesi literatürde görülen ortak yaklaşımdır. Bu yaklaşım yurtiçi talebin ithal ve yerli üretim malların bileşiminden, yerli üretimin ise yurtiçi talep ve ihraç mallarının bileşiminden oluştuğunun gösterilmesini mümkün kılmaktadır. Böylece HGD literatüründe oldukça yaygın olarak kullanılan Armington varsayımının SHM'yi temel veri seti olarak alan bir HGD modeli tarafından kullanılması mümkün hale gelmektedir.

SHM satır ve sütun toplamları birbirine eşit bir kare matris olduğu için üretim faaliyetleri sütununun sonundaki "toplam maliyetler" rakamı, aynı hesabın satırı sonundaki "toplam satışlar" rakamına eşit olmaktadır. Bu durumda "yurtiçi satışlar" matrisi, ilgili sektördeki "toplam satışlar" rakamından "ihracat" rakamının çıkartılmasıyla bulunabilir.

Ürünler sütunundaki "ithalat vergileri" (SHM'de satırda 43 sütunda 16-30 numaralı hesaplar) ilgili sektördeki ithalat vergisini ifade etmekte olup TÜIK'ten, "ithalat" rakamları ise ilgili sektörün ithalatının parasal değerini ifade etmekte olup (satırda 44 sütunda 16-30 numaralı hesaplar) toplulaştırılmış girdi-çıktı tablosundaki "ithalat" satırından alınmıştır.

\subsection{Faktörler Hesabı}

SHM'nin faktörler hesabı sektörler tarafından ödenen üretim faktörü ödemelerinin toplamından oluşmaktadır. Dolayısıyla SHM'de işgücü ve sermaye sütunları ile hane halkı satırının kesiştiği hücreler sırasıyla, üretim faaliyetleri sütununun işgücü hesabına ve sermaye hesabına yaptığı brüt ödemelerin sektörel toplamından oluşmaktadır.

Bu çalışmadaki SHM, daha önce belirtildiği gibi 10 farklı hane halkı gurubundan oluşmaktadır. Bu nedenle işgücü sütunu ve hane halkı satırının kesiştiği hücredeki "ücretler" (satırda 33-43, sütunda 31 numaralı hesap), $10 \times 1$ boyutunda bir vektörü ifade etmektedir. Aynı durum sermaye sütunu ile hane halkı satırının kesiştiği "sermaye geliri" (satırda 33-43, sütunda 32 numaralı hesap) için de geçerlidir.

Ücret ve sermaye faktör gelirleri, TüiK tarafından yayımlanan 2002 yılı hane halkı gelir dağılımı anketi kullanılarak 10 farklı hane halkı gurubuna ayrıştırılmıştır. Bunun için hane halkı gelir anketinden ilgili hane halkı gruplarının ücret gelirlerinden ne oranda pay aldığı hesaplanmış, SHM'de sektörlerin işgücüne yaptığı ödemelerin toplamı bu oranlar doğrultusunda hane halkı gruplarına dağıtılmıştır. Benzer yöntemle sermaye gelirleri hane halkı gelir anketlerinden yararlanılarak hane halkı gruplarına dağıtılmıştır.

\subsection{Hane Halkı Hesabı}

Hane halkı hesabı, hane halkının yerleşim yerine göre kır ve kent olmak üzere öncelikle ikiye, sonrasında her bir hane halkı grubu kendi içinde gelir seviyesine göre \% 20'lik gruplar halinde beşe ayrıştırılmıştır. Böylece hane halkı hesabı 10 farklı gruba ayrıştırılmıştır. Literatürdeki SHM'lerde hane halkı hesabı genellikle bu kadar ayrıştırılmamaktadır. Ancak bu çalışmanın temel amacı son yıllarda yapılan vergi politikası değişikliklerinin analiz edilmesi amacıyla oluşturulan bir HGD modeline temel veri seti teşkil edecek nitelikte bir SHM inşa etmek olduğundan, gelir dağılımı ve hane halkları arasındaki refah değişimlerinin analiz edilebilmesi amacıyla bu ayrıştırma önem kazanmaktadır.

Hane halkı sütunu, hane halkı gruplarının gelirlerini hangi alanlara harcadığını göstermekte, satırı ise bu gelirin hangi kaynaklardan geldiğini göstermektedir. Buna göre hane halkı grupları gelirlerini tüketim harcaması yapmakta, gelir vergisi ödemekte ve tasarruf etmekte kullanmaktadır. Bu kalemler Tablo 2'de sırasıyla "özel tüketim", "doğrudan vergiler" ve "özel tasarruflar" olarak gösterilmektedir. Hane halkı gelirlerini ise daha önce açıklanan "ücretler" ve "sermaye geliri" ile devlet hesabı açıklanırken değinilecek olan "transferler" ve dış alem hesabı anlatılırken bahsedilecek olan "net faktör gelirleri" oluşturmaktadir.

Hane halkı sütunda bulunan "özel tüketim" (satırda 16-30, sütunda 33-42 numaralı hesaplar), hane halkı sütunu ile ürünler satırının kesiştiği yerde bulunduğundan $15 \times 10$ boyutunda bir matristir. SHM'deki "özel tüketim", hane halkı gruplarına ayrıştırılmadan önce, ilk olarak toplulaştırılmış girdi-çıktı tablosunun nihai kullanımlar kısmındaki "hane halkı tüketim harcaması" hesabından alınmıştır. Ancak SHM'deki hane halkı hesabının satır sütun denkliğinin tutturulabilmesi için vergileri de içermesi gerekmektedir. Bu nedenle $15 \times 1$ boyutunda vektör olan "özel tüketim" rakamına net vergi matrisindeki "hane halkının nihai tüketim harcaması" vektörü eklenmiştir. Sonrasında TÜiK tarafından yayımlanan 2002 yılı hane halkı tüketim harcamaları anketi kullanılarak "özel tüketim" vektörü 10 hane halkı grubuna ayrıştırılarak 15×10 boyutundaki "özel tüketim" matrisi elde edilmiştir. Bunun için tüketim harcamaları anketi kullanılarak ilgili hane halkı gruplarının ilgili sektördeki özel tüketimin ne kadarlık kısmını gerçekleştirdiği oransal olarak hesaplanmış, bu oranlar SHM'deki her bir sektör için özel tüketimin hane halkı grupları arasında ayrıştırılmasında kullanılmıştır. 
Hane halkı sütunu ile devlet satırının kesiştiği yerde bulunan "doğrudan vergiler" (satırda 43 sütunda 33-42 numaralı hesap), 2002 yılı KKGD ve bütçe istatistiklerinden derlenmiş olup bütçedeki doğrudan vergilerin yanı sıra devlete yapılan sosyal güvenlik prim ödemelerini de kapsamaktadır. Bu hesaplardan oluşturulan "doğrudan vergiler" rakamı, hane halkı gelir dağılımı anketi kullanılarak 10 hane halkı grubuna ayrıştırılmıştır.

Hane halkı sütunundaki son kalem olan "özel tasarruflar" (satırda 44, sütunda 33-42 numaralı hesap), hane halkları tasarruflarını ifade etmektedir ve SHM içinde $\mathrm{RAS}^{8}$ yöntemi kullanılarak oluşturulmuştur. Oluşturulan rakamın hane halkı tüketim anketlerinden elde edilen tasarruf eğilimi rakamıyla tutarlı olduğu gözlemlenmiştir. Yine hane halkı gelir dağılımı anketleri kullanılarak "özel tasarruf" rakamı 10 hane halkı grubuna ayrıştırılmıştır.

\subsection{Devlet Hesabı}

Devlet sütunu kamu kesiminin gelirinin hangi alanlarda kullanıldığını göstermekte, satırı ise kamu geliri kaynaklarını göstermektedir. Buna göre kamu kesimi gelirini tüketim harcaması yapmakta, hane halkı gruplarına transfer ödemesi gerçekleştirmekte ve tasarruf etmekte kullanmaktadır. Kamu kesimi bu geliri, dolaylı vergilerden, ithalat vergilerinden ve doğrudan vergilerden elde etmektedir.

Devlet sütunu ile ürünler satırının kesiştiği yerde bulunan "kamu tüketimi" (satırda 16-30, sütunda 43 numaralı hesap), toplulaştırımış girdi-çıktı tablosundan elde edilmiş $15 \times 1$ boyutunda bir vektördür. Kamu tüketimine "özel tüketim" rakamlarında olduğu gibi net vergi matrisinden ilgili hesabın nihai harcama vergileri vektörü eklenmiştir.

Devlet sütunu ile hane halkı satırının kesiştiği yerde bulunan "transferler" (satırda 33-42, sütunda 43 numaralı hesap) rakamı, bütçe hesaplarından sosyal güvenlik ödemelerini ve hane halklarına yapılan diğer transferleri içeren hane halklarına transfer kaleminden oluşmaktadır. Bu çalışmada oluşturulan SHM'nin faiz oranlarını da içeren ayrıntılı bir finansal kesimin bulunmadığı bir HGD modelinde kullanılacağı varsayıldığından devletin borçlanmadığı, bu nedenle de faiz giderinin olmadığı varsayılmıştır. Dolayısıyla transfer ödemleri içinde yer alan faiz ödemeleri SHM oluşturulurken ihmal edilmiştir. Transfer ödemeleri rakamı, hane halkı gelir dağılımı anketine göre hane halkı gruplarına ayrıştırılmıştır.

Devlet sütunu ile birikim satırının kesiştiği yerde bulunan "kamu tasarrufu", devletin yatırımlarını finanse edecek şekilde oluşturulmuştur. KKGD ve bütçe hesaplarına göre bu rakam negatif olmaktadır. Ancak bu ça- lışmada devletin negatif tasarruf yapmadığı, diğer bir ifadeyle borçlanmadığı ve kamu yatırımlarını finanse edecek kadar tasarruf ettiği varsayılmıştır. Bunun için toplam yatırımlar içinde devlet yatırımlarının payı bulunmuş ve devlet bütçesinin bu rakam kadar fazla verdiği bir başka ifadeyle tasarruf ettiği varsayılmıştır.

\subsection{Birikim (Sermaye) Hesabı}

$\mathrm{Bu}$ çalışmada oluşturulan SHM'nin birikim hesabında devlet ve özel kesim şeklinde bir ayrıma gidilmemiştir. Birikim sütunu ekonomideki toplam tasarrufun kullanımını göstermekte, satırı ise bu tasarrufun kaynaklarını göstermektedir. Buna göre ekonomideki toplam tasarruflar hane halkı gruplarının özel tasarrufundan, kamu kesiminin tasarrufundan ve yurtdışı tasarruftan kaynaklanmaktadır. Bu tasarruf yatırım harcaması olarak kullanılmaktadır.

Birikim sütunu ile ürünler satırının kesiştiği yerde "yatırımlar" (satırda 16-30, sütunda 44) bulunmaktadır. Bu kısım toplulaştırılmış girdi-çıktı tablosundaki "gayri safi sermaye oluşumu" rakamına net vergi matrisinden elde edilen aynı hesabın vergileri eklenerek oluşturulmuştur.

\subsection{Dış Alem Hesabı}

Dış alem sütunu, yurtdışı ekonomilerden gelen gelirlerin kaynaklarını, satırı ise yurtdışı ekonomilere yapılan harcamaları göstermektedir. Buna göre ekonomideki toplam döviz gelirleri ihracat, net faktör gelirleri ve yabancı tasarruflardan kaynaklanmakta, döviz giderleri ise ithalat harcamalarından kaynaklanmaktadır.

Dış alem sütunu ile üretim faaliyetleri satırının kesiştiği yerde bulunan "ihracat" (satırda 1-15, sütunda 45 numaralı hesap), toplulaştırılmış girdi-çıktı tablosundan alınmıştır. Türkiye 2002 yılı net vergi matrisinde ihracat teşvikleri oldukça düşük olduğundan ihmal edilmiş ve toplulaştırılmış girdi-çıktı tablosundan alınan ihracat rakamlarına eklenerek ayrıca gösterilmemiştir.

Bu sütunda bulunan "net faktör gelirleri" (satırda 33-42, sütunda 45 numaralı hesap), dış ticaret istatistiklerinden elde edilmiş, sonrasında hane halkı gelir anketine göre hane halkı gruplarına ayrıştırılmıştır. Bu rakam yurtdışından gelen işçi gelirlerinin yanı sıra firmaların net döviz transferlerini de içermektedir.

SHM'de yer alan son rakam olan "dış kaynak" rakamı ise ticaret açığını dengelemek amacıyla RAS yöntemiyle bulunmuştur. Bu rakam ülkeye gelen yurtdışı tasarruflar ya da yabancı kaynak olarak düşünülebilir. Böylece SHM'nin yapısı ve Türkiye için 2002 yılına ait SHM'nin nasıl oluşturulduğu her bir hesap için açıklanmıştır. 


\section{SONUÇ}

Sosyal hesaplar matrisleri politika değiş̧ikliklerinin analiz edilmesi amacıyla geliştirilen birçok ekonomik model için temel bir araç ve seti olarak kullanılmaktadır. Bu nedenle bu çalışmada hesaplanabilir genel denge modelleri için temel veri seti teşkil edecek nitelikte Türkiye için 2002 yılına ait sosyal hesaplar matrisi oluşturulmuştur. Bu amaçla öncelikle SHM tanıtılmış ve temel yapısı açıklanmıştır. Sonrasında TÜík tarafından yayınlanan en güncel girdi-çıktı tablosu olan 2002 yılı girdi-çıktı tablosu temel alınarak 2002 yılı için Türkiye SHM'si oluşturulmuş, bu SHM'nin yapısı ve oluşturma yöntemi açıklanmıştır.

Bu çalışmada oluşturulan SHM, 15 sektörden oluşan üretim faaliyetleri ve ürünler hesabını, yerleşim yeri ve gelir düzeyine göre ayrıştırılmış 10 hane halkı grubunu, emek ve sermayeden oluşan üretim faktörlerini, devlet, birikim ve dış alem hesaplarını içer- mektedir. SHM'nin oluşturulmasına 2002 yılı girdi-çıktı tablosunun yanı sıra hane halkını ayrıştırmak için 2002 yılı hane halkı bütçe araştırması ve tüketim harcamaları anketlerinden, kamu gelir ve giderlerini belirlemek amacıyla KKGD istatistiklerinden ve dış alem hesabını oluşturmak için ödemeler dengesi istatistiklerinden faydalanılmıştır. Oluşturulan SHM'nin faiz oranlarını da içerecek şekilde ayrıntılı bir finansal sektörü içermeyen bir HGD modelinde kullanılacağı varsayımı altında, faiz ödemelerinin ve borçlanmanın olmadığı bir ekonomi kurgulanmış ve bu nedenle SHM'deki faiz ödemeleri çıkartılarak gerek hane halklarının gerekse devlet hesabının pozitif tasarruf yaptığı varsayılmıştır. Bu çalışmada oluşturulan SHM Türkiye ekonomisi için inşa edilen HGD vergi modeli yardımıyla son yıllarda Türkiye de yapılan vergi politikası değişikliklerinin analizinde veri seti olarak kullanılacaktır. 


\section{SON NOTLAR}

${ }^{1}$ SHM'nin tanımına ilişkin ayrıntılı tartışma ve kullanım alanları için bkz. King (1981), Pyatt (1988, 1991), Pyatt ve Round (1977).

2 Temel veri seti olarak SHM kullanan HGD modelleri hakkında literatür taraması için bkz. Bandara (1991) ve Sunal (2010).

3 Türkiye ekonomisine ait en son girdi çıktı tablosu 2002 yılına ait olduğu için bu yıl verileri kullanılarak SHM oluşturulmuştur.

${ }^{4}$ SHM'nin ortaya çıkışını sağlayan Stone'nun yürüttüğü çalışmalar hakkında bilgi için bkz Pyatt (1994a).

${ }^{5}$ Ulusal Hesaplar Sistemi hakkında ayrıntılı bilgi için bkz. Pyatt (1991), Miller \& Blair (2009).

6 Stone tarafından geliştirilen SNA hakkında bilgi için bkz. United Nations Statistical Office (1968).

${ }^{7}$ Bu çalışmada 2002 yılına ait Türkiye ekonomisi için oluşturulan 46x46 boyutundaki mikro SHM ekte verilmiştir.

${ }^{8}$ RAS (Row And column Sum) yöntemi SHM satır ve sütun toplamlarının birbirine eşit olması gerekliği ilkesinden yararlanarak bilinmeyen hücre değerinin tahmininde kullanılmaktadır.

\section{KAYNAKLAR}

Akkemik, K. A. (2012) "Assessing the Importance of International Tourism for the Turkish Economy: A Social Accounting Matrix Analysis" Tourism Management, 33(4):790-801.

Bandara, J. S. (1991) "Computable General Equilibrium Models for Development Policy Analysis in LDCs" Journal of Economic Surveys , 5(1):3-69.

Breisinger, C., Thurlow, J. ve Duncan, M. (2007) A 2005 Social Accounting Matrix (SAM) For Ghana, Washington, D.C., Ghana Statistical Services (GSS), International Food Policy Research Institute (IFPRI).

Chemingui, M.A. ve Dessus, S. (2008) "Assessing Non-tariff Barriers in Syria" Journal of Policy Modeling , 30(5):917-928.

De Santis, R.A. ve Ozhan, G. (1997) "Social Accounting Matrix for Turkey 1990" Economic Systems Research , 9(3):281-285.

Deb Pal, B., Pohit, S. ve Roy, J. (2012) "Social Accounting Matrix For India” Economic Systems Research, 24(1):77-99.

Debowicz, D., Dorosh, P., Robinson, S. ve Haider, S.H. (2012) "A 2007-08 Social Accounting Matrix for Pakistan" International Food Policy Research Institute Pakistan Strategy Support Program, Working Paper Series, No:1.

Decaluwé, B., Savard, L. ve Thorbecke, E. (2005) "General Equilibrium Approach for Poverty Analysis: With an Application to Cameroon" African Development Review, 17(2): 213-243.

Dewhurst, J., Kerwat, J. ve Molana, H. (2011) "Constructing a Social Accounting Matrix for Libya" The Journal of North African Studies, 16(1):143-160.
Erten, H. (2009) "Türkiye için Sektörel Sosyal Hesaplar Üretm Yöntemi ve İstihdam Üzerine Bir Hesaplanabilir Genel Denge Modeli Uygulaması" Yayınlanmamış Uzmanlık Tezi, Ankara, Devlet Planlama Teşkilatı.

Gedik, M.A. (2011) "A Comparative Analysis of Turkish Social Accounting Matrices for 1998 and 2002" International Research Journal of Finance and Economics, (75):39-54.

Gedik, M.A. (2010) "Vergi Politikalarinin Dis Ticaret Üzerindeki Etkileri:Türkiye Için Hesaplanabilir Genel Denge Modeli Uygulamasi" Maliye Dergisi , 159:395-415.

Iqbal, Z. ve Siddiqui, R. (1998) "Salient Features of the Social Accounting Matrix for Pakistan, 1989-90" Micro Impacts of Macroeconomic and Adjustment Policies Third Annual Meeting, November 2-6, Kathmandu, Nepal.

Karadag, M. ve Westaway, T. (1999) "A SAMbased Computable General Equilibrium Model of the Turkish Economy" Loughborough University Economic Research Paper, No: 99/18.

Keuning, S.J. ve Ruijter, W.A. (1988) "Guidelines to The Construction of A Social Accounting Matrix" Review of Income and Wealth, 34 (1):71-100.

King, B.B. (1981) "What is a SAM? A Layman's Guide to Social Accounting Matrices" World Bank Staff Working Papers, No: 463.

Konan, D.E. ve Maskus, K.E. (2000) "Joint Trade Liberalization and Tax Reform in a Small Open Economy: the Case of Egypt" Journal of Development Economics , 61(2):365-392. 
Köse, A.H. ve Yeldan, E. (1996) “Çok Sektörlü Hesaplanabilir Genel Denge Modellerinin Veri tabanı Üzerine Notlar: Türkiye 1990 Sosyal Hesaplar Matrisi" ODTÜ Gelişme Dergisi , 23(1):58-83.

Li, J.C. (2002) "A 1998 Social Accounting Matrix for Thailand" International Food Policy Research Institute TMD Discussion Paper, No: 95.

Mabugu, R. (2001) "Short-run Effects of Tariff Reform in Zimbabwe: Applied General Equilibrium Analysis" Journal of African Economies, 10(2):174-190.

Miller, R.E. ve Blair, P.D. (2009) Input-Output Analysis Foundations and Extentions, 2nd Edition, Cambridge, Cambridge University Press.

Nwafor, M., Diao, X. ve Alpuerto, V. (2010) “A 2006 Social Accounting Matrix (SAM) for Nigeria: Methodology and Results" International Food Policy Research Institute, No:NSSP007.

Powell, A.A. ve Gruen, F.H. (1968) “The Constant Elasticity of Transformation Production Frontier and Linear Supply System" International Economic Review, 9(3):315-328.

Pradhan, B.K., Sahoo, A. ve Saluja, M.R. (1999) "A Social Accounting Matrix for India, 1994-95" Economic and Political Weekly, 34(48):3378-3394.

Pyatt, G. (1988) "A SAM Approach to Modelling" Journal of Policy Modelling, 10(3):327-352.

Pyatt, G. (1991) "SAMs, The SNA and National Accounting Capabilities" Review of Income and Wealth, 37(2):177-198.

Pyatt, G. (1994a) "Modelling Commodity Balances: A Derivation of the Stone Model" Economic Systems Research , 6(1):5-20.

Pyatt, G. (1994b) "Modelling Commodity Balances in a Computable General Equilibrium Context" Economic Systems Research , 6(2):123-134.

Pyatt, G. (1999) "Some Relationships between T-Accounts, Input-Output Tables and Social Accounting Matrices" Economic Systems Research , 11(4):365-387.

Pyatt, G. ve Round, J.I. (1977) "Social Accounting Planning for Development Planning" The Review of Income and Health , 23(4):339-364.

Reinert, K.A. ve Roland-Holst, D.W. (1992) "A Detailed Social Accounting Matrix for the USA1988" Economic Systems Research , 4 (2): 173-188.

Robinson, S. (2006) "Macro Models and Multipliers: Leontief, Stone, Keynes, and CGE Models" Janvry et al. (eds.) Poverty, Inequality and Development: Essays in Honor of Erik Thorbecke, New York, Springer Science.
Robinson, S., Cattaneo, A. ve El-Said, M. (2001) "Updating and Estimating a Social Accounting Matrix Using Cross Entropy Methods" Economic Systems Research , 13(1):47-64.

Round, J.I. (2003a) "Constructing SAMs for Development Policy Analysis: Lessons Learned and Challenges Ahead" Economic Systems Research , 15(2):161-183.

Round, J.I. (2003b) "Social Accounting Matrices and SAM-based Multiplier Analysis" Bourguignon et al. (eds.) Evaluating the Poverty and Distributional Impact of Economic Policies (Technics and Tools). Washington D.C., World Bank.

Salem, H.H. (2004) “The Macroeconomic Social Accounting Matrix of Tunisia in 1996" Computational Economics, 1-14.

Saraçoğlu, D.Ş. (2008) "The Informal Sector and Tax on Employment: A Dynamic General Equilibrium Investigation" Journal of Economic Dynamics and Control, 32(2):529-549.

Shumway, C.R. ve Powell, A.A. (1984) "A Critique of the Constant Elasticity of Transformation (CET) Linear Supply System" Western Journal of Agricultural Economics, 9(2):314-321.

Sunal, S. (2010) "Gelişmekte Olan Ülkelerin İncelendiği Hesaplanabilir Genel Denge Modellerine Yönelik İki Dönemli Bir Karşılaştırma: Rassal Literatür Taraması" Dumlupınar Üniversitesi Sosyal Bilimler Dergisi, (26):213-247.

Telli, Ç. (2004) "Sosyal Hesaplar Matrisi Üretme Yöntemi ve Türkiye Uygulaması" Yayınlanmamış Uzmanlık Tezi, Ankara Devlet Planlama Teşkilatı.

Thissen, M. ve Lofgren, H. (1998) "A New Approach to SAM Updating with an Application to Egypt" Environment and Planning A , 30(11):1991-2003.

Ulussever, T. (2011) "A Welfare Policy Analysis in The Turkish Economy: A Simulation Based Macroeconomic Application of The Deficit Financing Policies" Journal of the Franklin Institute, 348(7):1416-1434.

United Nations Statistical Office (1968) A System of National Accounts, Studies in Methods, Series, New York, United Nations. 